\title{
FACILE, MILD AND CONVENIENT PREPARATION AND CHARACTERIZATION OF SOME NOVEL SCHIFF BASE LIGANDS FROM SYNTHETIC DIAMINES AND SALICYLALDEHYDE
}

\author{
Hossein Naeimi* and Arash Heidarnezhad \\ Department of Organic Chemistry, Faculty of Chemistry, University of Kashan, Kashan, 87317, \\ Iran
}

(Received October 18, 2013; revised October 1, 2014)

\begin{abstract}
Some novel Schiff base ligands have been prepared through condensation of salicylaldehyde with synthetic various primary diamines under mild reaction conditions. The used aromatic diamines were synthesized in good yields starting from low-cost commercially available materials. In these reactions, the Schiff base products have been afforded with excellent yields and appropriate reaction times. The structure of these ligands has been characterized by IR, ${ }^{1} \mathrm{H}$ NMR and ${ }^{13} \mathrm{C}$ NMR techniques.
\end{abstract}

KEY WORDS: Schiff base, Salicylaldehyde, Preparation, Ligand, Diamine

\section{INTRODUCTION}

Synthesis and application of Schiff base compounds have been highly considered in recent decades. Schiff base compounds especially their complexes have been used in many reactions as important and significant compounds. Schiff base complexes because of their structures that are similar to the porphyrin and phthalocyanine rings have been highly considered in inorganic, organic and biological fields [1]. They are effective at loading oxygen, resisting bacteria and mimicking enzymes [2]. Much interest have been paid to the ionophore ligand as sensing materials for neutral carrier type ion-selective electrodes due to the unique properties of the compounds [3]. The formation of strong complex with good selectivity between some Schiff bases and different cations has been introduced. These compounds have been used for preparing ion-selective electrodes for determination of cations in solution with potentiometric methods [4]. Cooperative biometallic catalysis has been documented in several recently reported such as asymmetric epoxide ring opening reaction [5-9]. In such systems that metal is complexed with special Schiff bases, one metal is proposed to serve as Lewis acid for epoxide activation and another as counter ion for the nucleophile [10], reaction of some epoxides with elemental iodine and bromine in the presence of catalytic amounts of Schiff base complexes of metal(II) for preparation of haloalcoholes in high yields and regioselectivity [11], mimic peroxidase in the oxidation of phenol hydrogen peroxides in the presence of Schiff base complexes of Mn(III). The oxidation of styrene by molecular oxygen with Schiff base compounds as catalyst [12], are examples from application of Schiff base compounds and their complexes in chemical reactions. The rapidly emerging field of hetero-binucleating ligands and the coordination chemistry of the heteronuclear complexes derived from such ligands, have prompted an extension of our work on the synthesis of these ligands from condensation reactions of salicylaldehyde with the synthetic diamines [13-17].

In continuation of our research on the synthesis of Schiff bases and their complexes of metal ions [18-19], we have studied the preparation of several new Schiff bases from the reaction of salicylaldehyde with synthetic diamines in methanol solution under mild conditions. The corresponding products were identified and characterized by spectroscopic and physical data.

${ }^{*}$ Corresponding author. E-mail: naeimi@kashanu.ac.ir 


\section{EXPERIMENTAL}

\section{Materials}

Chemical were purchased from the Merck Chemical Company in high purity. All the materials were of commercial reagent grade. The synthetic diamines, aldehydes and solvents were purified by standard procedures.

\section{Apparatus}

The FT-IR spectra were obtained with potassium bromide pellets in the range $400-4000 \mathrm{~cm}^{-1}$ with a Perkin Elmer 550 spectrometer. ${ }^{1} \mathrm{H}$ NMR and ${ }^{13} \mathrm{C}$ NMR spectra were obtained at 500 $\mathrm{MHz}$ using an Bruker Avance spectrometer in $\mathrm{CDCl}_{3}$ and $\mathrm{DMSO}-\mathrm{d}_{6}$ as the solvents and chemical shifts are expressed in ppm using TMS as internal standard. Mass spectra were recorded on an Agilent Technology (HP) MS Model: 5973 Network Mass Selective Detector Instrument by Electron Impact (EI) Ionization mode with an ionization voltage of $70 \mathrm{eV}$. Melting points were obtained with a Yanagimoto micro melting point apparatus and are uncorrected. The purity determination of the substrates and reactions monitoring were accomplished by TLC on silica gel polygram SILG/UV 254 plates.

\section{Synthesis of diamines}

The diamines were synthesized according to the previously reported literatures [20-22].

A typical procedure for preparation of 4,4'-diamino stilbene (4)

To a solution of $p$-nitrotoluene $(6.8 \mathrm{~g}, 0.05 \mathrm{~mol})$ in $100 \mathrm{~mL}$ of diethylene glycol, a solution of $(11 \mathrm{~g}, 0.19 \mathrm{~mol})$ potassium hydroxide in $30 \mathrm{~mL}$ of water and $10 \mathrm{~mL}$ hydrazine hydrate $85 \%$ was added. The resulting mixture was refluxed with stirring for about twenty minutes and then the condenser was removed to allow the aqueous liquor to evaporate and temperature of the reaction mixture to rise about $200{ }^{\circ} \mathrm{C}$, refluxing at this temperature was continued for three hours. Then the mixture was cooled and diluted with cold water and the separated amino product was filtered off and recrystallized in acetone-ethanol which gave the pure product as brown crystalline.

A typical procedure for preparation of 4,4'-diamino stilbene-2,2'-disulfonic acid (5)

A solution of potassium hydroxide $(3 \mathrm{~g}, 52 \mathrm{mmol})$ in low amount of water was slowly added with stirring to a mixture of $p$-nitrotoluene orthosulfonic acid $(2.2 \mathrm{~g}, 10 \mathrm{mmol})$, diethylene glycol $(20 \mathrm{~mL})$ and $2.5 \mathrm{~mL}$ of hydrazine hydrate $85 \%$. The resulting mixture was refluxed for 30 min, then the condenser was removed and the aqueous liquor was evaporated and refluxing continued for 2.5 hours. When the reaction was completed, the reaction mixture was cooled and diluted with water. Then the cooled and diluted reaction mixture was acidified with warm concentrated hydrochloric acid and the pure product was filtered.

A typical procedure for preparation of 4,4-diamino azobenzene (6)

A mixture of glacial acetic acid $(100 \mathrm{~mL}), 5.8 \mathrm{~g}$ of $p$-amino acetanilide, $8 \mathrm{~g}$ of sodium perborate tetrahydrate and $2 \mathrm{~g}$ of boric acid were heated with stirring to $50-60{ }^{\circ} \mathrm{C}$ and hold in this temperature for 6 hours. At the end of reaction, the mixture was cooled and the yellow product filtered off and washed with water, then the product 4,4-bis(acetamido)azobenzene with the mixture of $30 \mathrm{~mL}$ methanol and $30 \mathrm{~mL}$ of $6 \mathrm{~N}$ hydrochloric acid was hydrolyzed for 1.5 hours. 
Facile and convenient preparation and characterization of some novel Schiff base ligands 119

The reaction mixture was filtered off and the product neutralized by the addition of $2.5 \mathrm{~N}$ sodium hydroxide. Finally, the amino product filtered, washed with water and dried under reduced pressure.

Synthesis of Schiff base ligands

A typical procedure for preparation of Schiff bases 7 and 9

In a $50 \mathrm{~mL}$ round-bottom flask with $10 \mathrm{~mL}$ absolute methanol, $(0.5 \mathrm{~g}, 2.3 \mathrm{mmol})$ of 4,4'-diamino azobenzene for preparation of Schiff base (7) and in another round-bottom flask with $10 \mathrm{~mL}$ absolute methanol ( $0.5 \mathrm{~g}, 2.25 \mathrm{mmol})$ of 4,4'-diamino stilbene for preparation of Schiff base (9) was added and temperature was raised to $60-70{ }^{\circ} \mathrm{C}$ and stirring was continued until the diamines was solved. Then, salicylaldehyde $(0.56 \mathrm{~g}, 4.6 \mathrm{mmol})$ in $5 \mathrm{~mL}$ absolute methanol for Schiff base (7) and (0.55 g, $4.5 \mathrm{mmol})$ for Schiff base (9) was added and resulting mixtures was refluxed for about $10-15 \mathrm{~min}$. When the reaction was completed the mixtures was cooled and products was filtered off, washed with absolute methanol and dried.

Synthesis of Schiff base ligands

A typical procedure for preparation of Schiff base $\mathbf{8}$

To a stirred solution of 4,4'-diamino stilbene-2,2'-disulfonic acid (1 g, $2.6 \mathrm{mmol})$ in absolute methanol $(20 \mathrm{~mL})$, a solution of $(0.1 \mathrm{~g}, 2.5 \mathrm{mmol})$ potassium hydroxide in $5 \mathrm{~mL}$ of absolute methanol was added drop wise over a period of $5 \mathrm{~min}$ at room temperature. After the addition of base solution, salicylaldehyde $(0.66 \mathrm{~g}, 5.4 \mathrm{mmol})$ in absolute methanol $(10 \mathrm{~mL})$ was added and the resulting mixture refluxed for about $30 \mathrm{~min}$. The progressive and completion of the reaction were monitored by TLC. When the reaction was completed, the brown precipitate was filtered off and the filtrate was washed with absolute methanol and by evaporating the solvent gave the desired product as red crystalline.

4,4-diaminostilbene. IR/v (KBr) $\mathrm{cm}^{-1}$ : 3350-3370, 2930-3000, 1620-1660, 1510. ${ }^{1} \mathrm{H} \mathrm{NMR}$ $\left(\mathrm{DMSO}_{6}, 500 \mathrm{MHz}\right) \delta(\mathrm{ppm}): 8.02(\mathrm{~d}, 4 \mathrm{H}), 7.6(\mathrm{~d}, 4 \mathrm{H}), 7.55(\mathrm{~d}, 2 \mathrm{H}), 3.5(\mathrm{~s}, 4 \mathrm{H}) . \mathrm{MS}(\mathrm{EI}$, $\mathrm{m} / \mathrm{z}): 210(\mathrm{M}+, 85), 184$ (59), 118 (37).

4,4'-Diaminostilbene-2,2'-disulfonic acid. IR/v (KBr) $\mathrm{cm}^{-1}:$ 3400-3500, 2750-3200, 1490-1610, 1180, 1080. ${ }^{1} \mathrm{H}$ NMR (DMSO-d 6 , $\left.500 \mathrm{MHz}\right) \delta(\mathrm{ppm}): 8-11(\mathrm{~s}, 2 \mathrm{H}), 7.71(\mathrm{~d}, 2 \mathrm{H}), 7.6(\mathrm{~d}, 2 \mathrm{H}), 7.2$ (s, 2H) $7.20(\mathrm{~d}, 2 \mathrm{H}), 3.52$ (s, 4H). MS (EI, $m / z): 370(\mathrm{M}+, 10), 208(30)$.

4,4'-Diaminoazobenzene. IR/v (KBr) cm ${ }^{-1}: 3350,3110,1585,1400 .{ }^{1} \mathrm{H}$ NMR (DMSO-d, 500 MHz) $\delta$ (ppm): $7.82(\mathrm{~d}, 4 \mathrm{H}), 6.74(\mathrm{~d}, 4 \mathrm{H}), 5.72(\mathrm{~s}, 4 \mathrm{H}) .{ }^{13} \mathrm{C}$ NMR (DMSO-d 6 ) $\delta(\mathrm{PPM}) 149$, 145, 125, 114. MS (EI, m/z): 212 (M+, 40), 184 (65).

$N, N^{\prime}$-bis(salicylidine)-4,4'-diaminostilbene. IR/v (KBr) $\mathrm{cm}^{-1}:$ 3320-3500, 2940-2990, 1605, 1150, 1130. ${ }^{1} \mathrm{H}$ NMR (DMSO-d $\left.{ }_{6}, 500 \mathrm{MHz}\right) \delta(\mathrm{ppm}): 13(\mathrm{~s}, 2 \mathrm{H}), 8.5$ (s, 2H), 7-7.9 (m, 16H), $6.8(\mathrm{~d}, 2 \mathrm{H})$. MS (EI, $m / z): 418(\mathrm{M}+, 7), 392(11)$.

$N, N^{\prime}$-bis(salicylidine)-4,4'-diaminostilbene-2,2'-disulfonic acid. IR/v (KBr) cm$~^{-1}:$ 3100-3490, 3030, 1610, 1470, 1160, 1140. ${ }^{1} \mathrm{H}$ NMR (DMSO-d, $\left.500 \mathrm{MHz}\right) \delta(\mathrm{ppm}): 10.8$ (s, 2H), 9.80 (s, 2H), $9.76(\mathrm{~s}, 4 \mathrm{H}), 7.84(\mathrm{~s}, 4 \mathrm{H}), 7.32(\mathrm{~m}, 2 \mathrm{H}), 6.9(\mathrm{~d}, 4 \mathrm{H}), 6.6(\mathrm{~s}, 4 \mathrm{H})$. MS (EI, $m / z): 578(\mathrm{M}+, 2)$, $552(8)$. 
$N, N^{\prime}$-bis(salicylidine)-4,4'-diaminoazobenzene. IR/ $v(\mathrm{KBr}) \mathrm{cm}^{-1}: 3310-3450,3030,1609,1170$, 1150. ${ }^{1} \mathrm{H}$ NMR (DMSO-d 6 , $\left.500 \mathrm{MHz}\right), \delta(\mathrm{ppm}): 13.31(\mathrm{~s}, 2 \mathrm{H}), 8.73(\mathrm{~s}, 2 \mathrm{H}), 8.07(\mathrm{~d}, 4 \mathrm{H}), 7.42$ (m, 4H), 7.36 (m, 2H), 7.27 (q, 4H), 6.22 (t, 2H). MS (EI, m/z): $420(\mathrm{M}+, 40), 392$ (18).

\section{RESULTS AND DISCUSION}

In this research, firstly the aromatic diamines $\mathbf{4 , 5}$ and $\mathbf{6}$ have been synthesized from compounds 1, 2 and 3 respectively (Scheme 1). These diamines were easily prepared in good yields by starting from low-cost commercially available materials. The corresponding results of these reactions are indicated in Table 1. As shown in Table 1, the overall yield of the diamine 1 from $p$-nitrotoluene is $32 \%$ and the overall yields for 2 and 3 diamines are $73 \%$ and $52 \%$ respectively. In IR spectra, the presence of $-\mathrm{NH}_{2}$ group stretching bands in the $3300-3500 \mathrm{~cm}^{-1}$ region for diamines, the lack of $\mathrm{HNC}=\mathrm{O}$ group stretching band in the $1720 \mathrm{~cm}^{-1}$ region for diamine $3,{ }^{1} \mathrm{H}$ $\mathrm{NMR}$ and ${ }^{13} \mathrm{C}$ NMR data are completely consistent with the formulation indicated in Scheme 1.

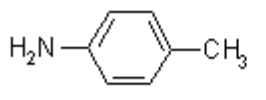

1

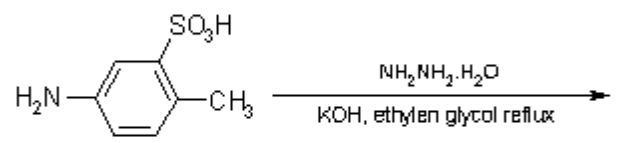

2

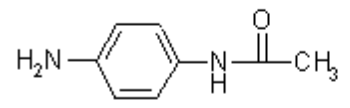

3

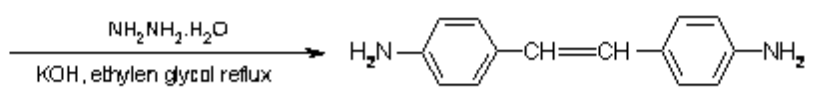

4

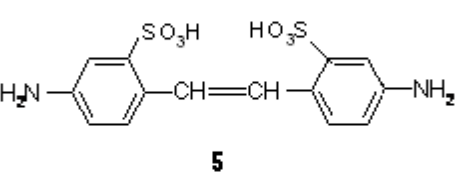

5

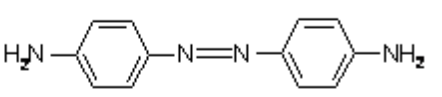

sodium perborate tetrabydrate

6

Scheme 1

Table 1. The results of related to the prepared diamines

\begin{tabular}{|c|l|c|c|c|c|}
\hline Entry & Substrate & Reaction time $(\mathrm{h})$ & Yield $^{\mathrm{a}}(\%)$ & Product & m.p. $/{ }^{\circ} \mathrm{C}[\mathrm{Ref}]$. \\
\hline 1 & $p$-Nitrotoluene & 3.2 & 32 & 4 & $226-228[20]$ \\
\hline 2 & $p$-Nitrotoluene orthosulfonic acid & 3 & 73 & 5 & $>400[20]$ \\
\hline 3 & $p$-Aminoacetanilide & 6 & 52 & 6 & $238-241[22]$ \\
\hline
\end{tabular}

${ }^{\text {a }}$ Isolated yields based on concern substrates.

In continuation, the reaction of salicylaldehyde with the prepared diamines was carried out (Scheme 2). The Schiff base ligands 7, 8 and $\mathbf{9}$ were easily prepared by refluxing and stirring two equivalents of salicylaldehyde with one equivalent of the diamines 4, 5 and 6 respectively in anhydrous methanol. The obtained results are summarized in Table 2. As can be seen in Table 2, these ligands have been afforded in $70-85 \%$ yields and reaction times at $10-30 \mathrm{~min}$. The completion condensation of all primary amino groups was confirmed by the lack of $\mathrm{NH}_{2}$ stretching bands in the $3300-3500 \mathrm{~cm}^{-1}$ regions and the presence of strong stretching bands in the $1590-1610 \mathrm{~cm}^{-1}$ region in IR spectra. The ${ }^{1} \mathrm{H}$ NMR, ${ }^{13} \mathrm{C}$ NMR and IR data for compounds 7, $\mathbf{8}$ and $\mathbf{9}$ are completely consistent with the formulation indicated in Scheme 2. 


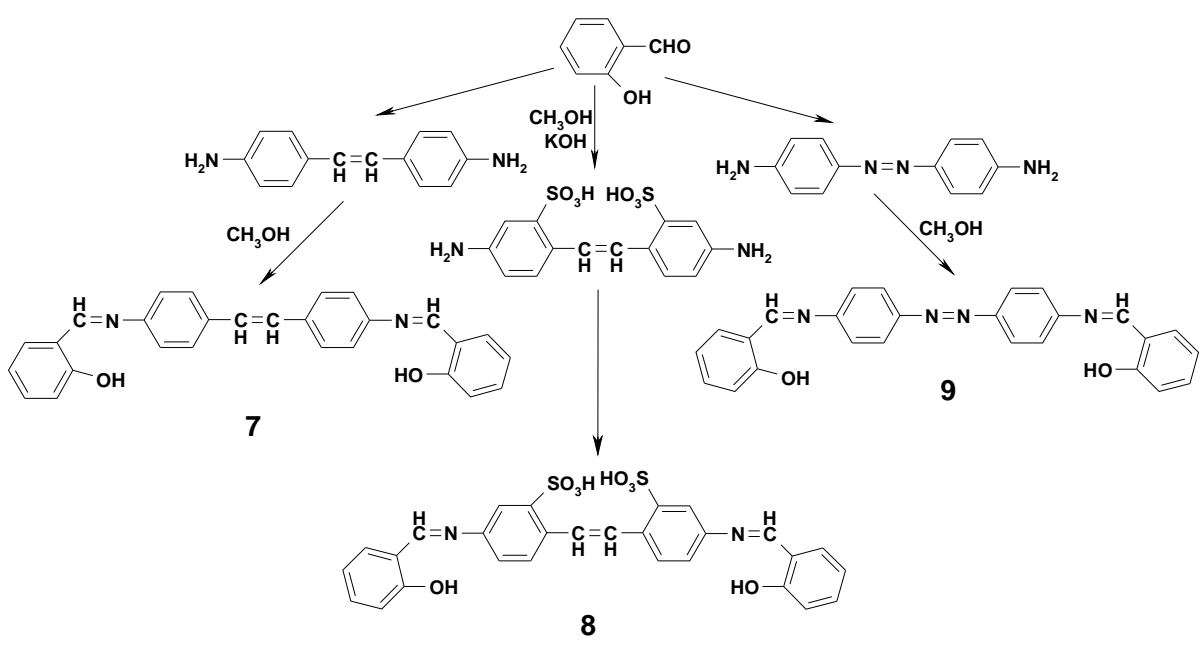

Scheme 2

Table 2. The obtained results for synthesized Schiff bases from salicylaldehyde and synthetic diamines.

\begin{tabular}{|c|l|c|c|l|c|}
\hline Entry & Substrate & Reaction time (min) & Yield ${ }^{\mathrm{a}} \%$ & Product & m.p. $\left({ }^{\circ} \mathrm{C}\right)$ \\
\hline 1 & $4,4^{\prime}$-diaminostilbene (4) & 15 & 85 & $\begin{array}{l}\text { N,N'-bis(salicylidine)-4,4'- } \\
\text { diaminostilbene (7) }\end{array}$ & $240-244$ \\
\hline 2 & $\begin{array}{l}4,4^{\prime} \text {-diaminostilbene } \\
2,2^{\prime} \text {-disulfonic acid (5) }\end{array}$ & 35 & 80 & $\begin{array}{l}\text { N,N'-bis(salicylidine)-4,4'- } \\
\text { diaminostilbene-2,2'-disulfonic acid } \\
(\mathbf{8})\end{array}$ & $>400$ \\
\hline 3 & $\begin{array}{l}4,4^{\prime} \text {-diaminoazobenzene } \\
(\mathbf{6})\end{array}$ & 15 & 70 & $\begin{array}{l}\text { N,N'-bis(salicylidine)-4,4'-diamino } \\
\text { azobenzene (9) }\end{array}$ & $>300$ \\
\hline
\end{tabular}

${ }^{a}$ Isolated yields based on salicylaldehyde.

\section{CONCLUSION}

This study describes the synthesis of a new Schiff base ligands derived from salicylaldehyde with synthetic various primary diamines. In conclusion, we have reported a mild, easy, clean and a highly efficient method for the synthesis of some novel Schiff bases under mild conditions. The products have been obtained in high yields and short reaction times. The structure of products has been assigned by physical and spectroscopic data such as ${ }^{1} \mathrm{H} \mathrm{NMR},{ }^{13} \mathrm{C}$ NMR, infrared (IR), mass spectra and melting points.

\section{ACKNOWLEDGEMENT}

The authors are grateful to University of Kashan for supporting this work by Grant No. $159148 / 19$. 


\section{REFERENCES}

1. Breslow, R.S.; Dong, D. Chem. Rev. 1998, 98, 1997.

2. Doyle, M. P.; Forbes, D. C. Chem. Rev. 1998, 98, 911.

3. Ammann, D.; Morf, W.E.; Anker, P.; Meier, P.C.; Pretsch, E.; Simon, W. Ion Selective Electrode Rev. 1983, 5, 3.

4. Mazloum Ardakany, M.; Ensafi, A.A.; Naeimi, H.; Dastanpour, A.; Shamelli, A. Russ. J. Electrochem. 2003, 39, 269.

5. Hansen, K.B.; Leighton, J.L.; Jacobsen, E.N. J. Am. Chem. Soc. 1996, 118, 10924.

6. Tokunaga, M.; Larrow, J.F.; Kakiuchi, F.; Jacobsen, E.N. Science 1997, 277, 936.

7. McCleland, B.W.; Nugent, W.A.; Finn, M.G. J. Org. Chem. 1998, 63, 6656.

8. Matsunaga, S.; Dos, J.; Roles, J.; Vogel, E.M.; Yamamoto, N.; Iida, T.; Yamaguchi, K.; Shibasaki, M. J. Am. Chem. Soc. 2000, 122, 2252.

9. Schaus, S.E.; Jacobsen, E.N. Org. Lett. 2000, 2, 1001.

10. Joseph, M.; Jacobsen, R.; Eric, N. J. Am. Chem. Soc. 2001, 123, 2687.

11. Sharghi, H.; Naeimi, H. Bull. Chem. Soc. Jpn. 1999, 72, 1525.

12. Khandar, A. A.; Nejati, K.; Rezvani, Z. Molecules 2005, 10, 302.

13. Naeimi, H.; Rabiei Kh.; Salimi, F. Phosphorus, Sulfur, Silicon and Related Elements, 2009, $184,2351$.

14. Van Veggel, F.C. J.; Verboom, M.W.; Reinhoudt, D.N. Chem. Rev. 1994, 94, 279.

15. Beer, P.D. Adv. Inorg. Chem. 1992, 39, 79.

16. Beer, P.D. Endeavour. 1992, 16, 182.

17. Beer, P.D.; Gale, P.A.; Chen, G.Z. Coord. Chem. Rev. 1992, 39, 79.

18. Naeimi, H.; Safari, J.; Heidarnezhad, A. Dyes Pigm. 2007, 73, 251.

19. Sharghi, H.; Khaledi, H.N. Iran J. Chem. Chem. Eng. 1999, 18, 72.

20. Minlon, H. J. Am. Chem. Soc. 1948, 70, 2802.

21. Hein, D.W.; Pierce, S.E. J. Am. Chem. Soc. 1954, 76, 2527.

22. Santurri, P.; Frederick, R.; Stuboings, R. Org. Synth. 1960, 40, 18. 